\title{
ENVIRONMENTAL MANAGEMENT SYSTEMS IN THE AUTOMOTIVE SUPPLY CHAIN IN SOUTH AFRICA: A PILOT STUDY
}

\author{
A.C. Brent ${ }^{1,2}$ and S. Premraj ${ }^{1}$ \\ ${ }^{1}$ Chair of Life Cycle Engineering, Graduate School of Technology Management \\ University of Pretoria, South Africa \\ alan.brent@up.ac.za \\ ${ }^{2}$ Resource Based Sustainable Development \\ Natural Resources and the Environment \\ CSIR, South Africa
}

\begin{abstract}
Automobile Original Equipment Manufacturers (OEMs) have implemented formal Environmental Management Systems (EMSs) globally that require the OEMs to consider the environmental performance and potential liabilities in the supply chain. However, in South Africa, OEMs typically experience resistance from suppliers to focus on environmental issues, compliance with regulations, and OEM requirements. Although the responses from many OEMs have been an attempt to enforce the formal EMS certification and accreditation of suppliers, a case study reveals that such certification and accreditation does not necessarily imply good environmental performance, nor indeed environmental compliance with the national legislation. Apart from general environmental management and compliance information, basic cleaner production process parameters, i.e. water and energy usage, and waste generated, were used to compare the environmental performances of different sized suppliers, with and without formal EMSs, and with variance of financial dependency on an OEM. In order to improve the environmental performance of the entire supply chain, a conceptual model is introduced, which is currently under investigation in the automotive sector of South Africa.
\end{abstract}

\section{OPSOMMING}

Oorspronklike Toerusting Vervaardigers (OTVs) in die motorbedryf het internasionaal formele Omgewingsbestuursisteme (OBS) geïmplementeer wat vereis dat die omgewingsprestasie en potensiële aanspreeklikhede van die verskaffingsketting in ag geneem moet word. Nieteenstaande ondervind OTVs in Suid-Afrika weerstand van verskaffers wanneer gefokus word op omgewingsaspekte, voldoening aan regulasies en OTV-verwagtinge. Alhoewel die meerderheid OTVs formele OBS akkreditering probeer afdwing, toon 'n gevallestudie dat dit nie noodwendig omgewingsprestasie, en voldoening aan nasionale omgewingswetgewing, impliseer nie. Afgesien van algemene omgewingsbestuur en regsvoldoening, was produksieprosesparameters, soos water- en energieverbruik, en afvalgenerering, gebruik om die omgewingsprestasie van verskillende verskaffers, met of sonder OBS, en met variasie in finansiële afhanklikheid van 'n OTV, te vergelyk. Om die omgewingsprestasie van die verskaffingsketting te verbeter, word 'n konsepsuele model wat tans in the motorvervaardigingsektor van Suid-Afrika ondersoek word, voorgestel. 


\section{INTRODUCTION}

Internationally, industry has experienced mounting pressure to align operational processes with the objectives of sustainable development [1]. Apart from pressure drivers, push, pull, and support drivers have also been identified for the incorporation of sustainability into business practices (see Figure 1) [2]. The consequence is the concept of "business helping business improve environmental, health and safety performance, shareholder value, and corporate citizenship” [3]. Such initiatives have assisted many larger companies to adopt good environmental practices through formal Environmental Management Systems (EMSs), but it is often found that the suppliers of these companies have few or no environmental programmes, and little or no awareness or legal compliance $[4,5]$. Although it is often true that small and medium enterprises (SMEs) have lower environmental impacts than the larger companies they supply, it has been estimated that they collectively contribute between $70 \%$ and $95 \%$ of environmental impacts worldwide [5]. Therefore, it is imperative that industry understands that sound EMSs imply that good environmental performances and compliance of the entire supply chain, including SMEs, must be ensured [6, 7]. Furthermore, a good link between an EMS and the supply chain, if properly integrated with other business practices, could result in increased profitability (and quality) together with reduced environmental liabilities $[8,9]$.

- Introduction of sustainable development into government policies

- Investors looking for evidence of good corporate governance and effective management of risk

- Employees
- Civil society expectations

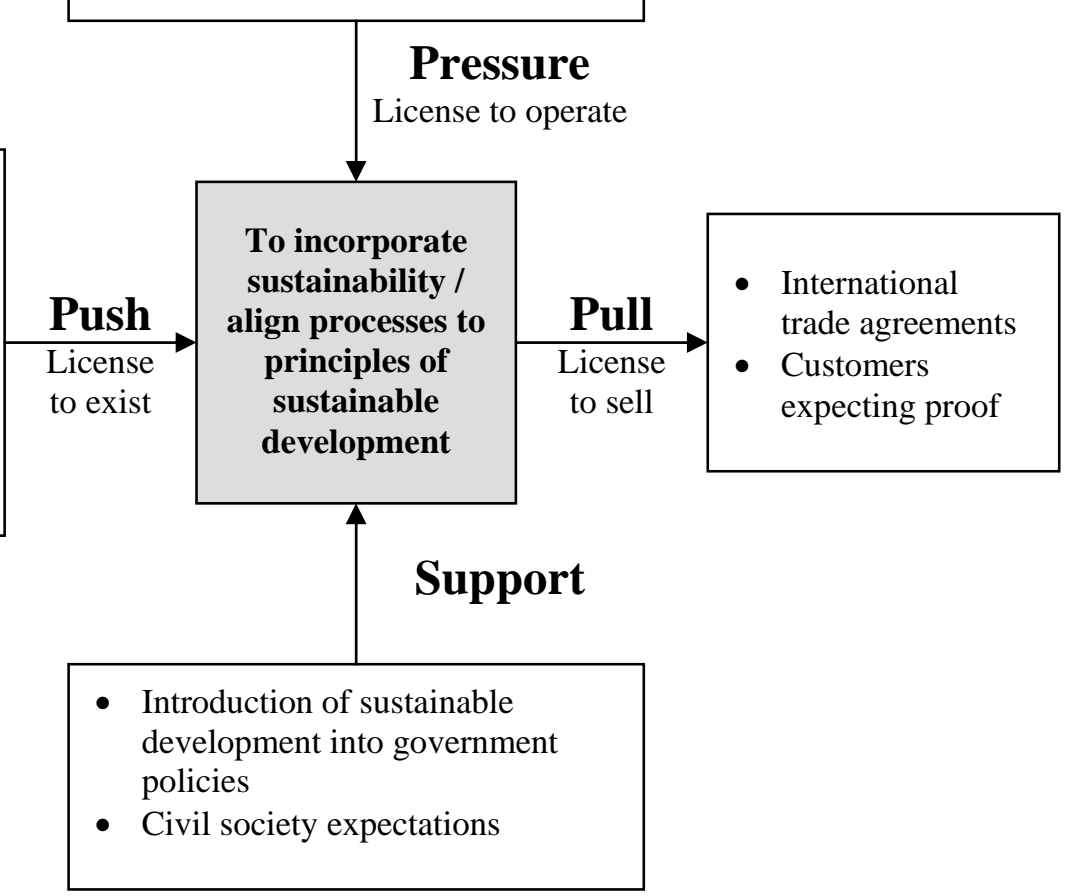

Figure 1: Drivers for the incorporation of sustainable development into business practices [2] 
The automotive sector of South Africa faces problems in that suppliers find it difficult to comply with the multitude of requirements of the multinational Original Equipment Manufacturers (OEMs). For example, it is a requirement for first tier suppliers to be TS 16949 accredited, and it is a further requirement from OEMs and TS 16949 that the suppliers have or are in the process of having ISO 14000 accreditation in addition to being ISO 9000 accredited. For products entering the European Union marketplace, it is also a requirement to register materials on the Substance of Concern (SOC) website. These are just a few of the requirements placed on suppliers in the last five years or so, and the strain on suppliers, typically medium and small companies, is manifesting itself in some companies either ceasing to trade completely, or ceasing to trade in the automotive sector specifically.

With respect to EMS implementation many suppliers, especially SMEs, lack the skills and knowledge to address the integration of an EMS with normal internal management practices. There is also very little assistance for suppliers in the form of tools, programmes, and policies to evaluate operations, to determine the extent of potential environmental impacts, and to identify possible solutions, which are typically available in developed and transition economies [10]. Although suppliers may be aware that their current business practices have certain impacts on the environment, and changes in operational practices are subsequently necessary, the perception is that these changes of practices would be costly and difficult to implement. Such barriers to SMEs adopting formal EMSs have even been highlighted in developed countries [11]:

- Internal barriers that are grouped into resources, understanding and perception, implementation, and attitudes and company culture.

- External barriers that are grouped into certifiers or verifiers, economics, institutional weaknesses, and support and guidance.

A comprehensive study conducted in the value chain of the manufacturing sector of the United States [12] further emphasised the following issues pertaining to the implementation of formal EMSs:

- $\quad$ EMSs are, in general, perceived as having a strong negative impact on the major strategic dimensions of performance, e.g. lead-time, cost, and quality, and EMSs do not enhance a company's competitive position in the marketplace.

- $\quad$ The implementation of an EMS is influenced by several factors: company size (larger companies more readily implement EMSs); nature of ownership (foreign-owned companies are more likely to implement EMSs); past success with the implementation of Total Quality Management (TQM) systems; and the degree to which cross-functional programmes and teams are used.

- Formal EMSs do lead to improved environmental performances, i.e. manufacturing plants can be both clean, or more environmentally responsible, and more efficient.

These findings have been confirmed in Europe [13]. Most notably, EMSs are more readily accepted where environmental improvements are complemented by cost- 
savings, although EMSs rarely fulfil the expectations of cost reduction potentials within companies [13]. The overall cost benefits associated with environmental management in the supply chain are therefore not recognised or integrated into the internal management practices of supplying companies.

There are supply chain models that attempt to ensure more effective supply chain management to reduce cost, lead-times, and improve product quality, e.g. the Supply Chain Operation Reference (SCOR) model of the Supply Chain Council [14]. This is a process reference model that improves the communication within and between organisations. It allows the management of companies, e.g. OEMs, to align goals and targets with supply chains to provide more effective planning and efficient operations [15]. Furthermore, SCOR can be used to measure and evaluate supply chain performance against set targets and business goals, thereby supporting the transfer of best practice and strategy planning. However, the type of models and tools that are available for automotive supply chain management have very little or no integration with EMSs, and therefore do not address the environmental concerns and business goals of OEMs.

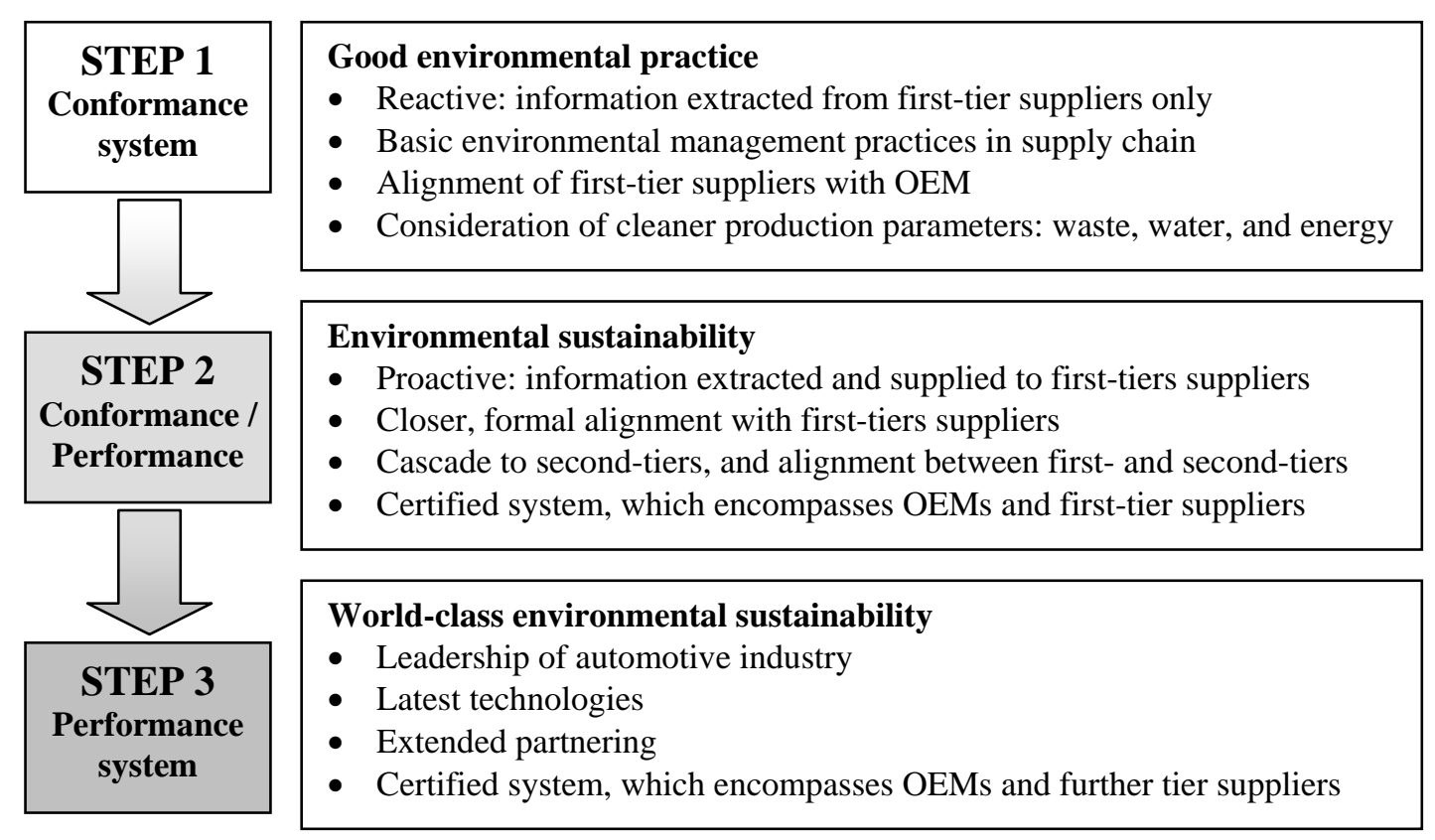

Figure 2: Supply chain environmental performance achievement goal

\subsection{Objectives of this paper}

This paper summarises the first phase of ongoing research work that has been undertaken in the automotive sector of South Africa. The primary objective of the paper is to evaluate and establish a preliminary baseline of the current automotive supply chain situation in South Africa with respect to the implementation of EMSs and environmental performances. For the preliminary baseline, only first-tier suppliers are considered. Sound EMSs of an OEM and all of its first-tier suppliers are viewed to be good environmental practice and the first step towards a world-class 
supply chain environmental performance achievement goal (see Figure 2). A rating procedure is introduced to evaluate the environmental performances of suppliers, and to prioritise where the emphasis must be placed in terms of supplier assistance to improve the overall environmental performance of the value chain. The rating procedure, based on Cleaner Production principles [16], is used to compare the environmental performances of different size suppliers, with and without formal EMSs, and with variance of financial dependency on an OEM.

Finally, a model is proposed, based on the findings, which could facilitate the implementation of EMSs and potentially lead to continuous environmental improvements in the whole supply chain.

\section{RESEARCH METHODOLOGY}

One Original Equipment Manufacturer (OEM), located in the Gauteng Province of South Africa, was considered as a case study. The OEM had forty-eight first-tier main component suppliers with manufacturing facilities inside South Africa. A simple electronic survey was designed to obtain the minimum environmental performance information from the first-tiers, which required little effort on the part of the companies. The information of the survey was verified with telephonic interviews and site visits. The survey required the following information:

- $\quad$ Products that are supplied to the OEM.

- $\quad$ Size of the company [17], i.e. small (fewer than 50 employees), medium (fewer than 500 employees), and large (more than 500 employees).

- $\quad$ Percentage of production allocated to the specific OEM, i.e. small dependency on OEM (less than $10 \%$ of production), medium dependency (less than 50\%), and large dependency (more than 50\%).

- Accreditation of the company with respect to environmental, safety, and quality management.

- $\quad$ Cleaner production process parameters and management practices, i.e. water usage and effluent releases, energy usage, and general and hazardous waste generation.

For the cleaner production (CP) factors - i.e., process parameters and management practices - scoring scales were developed from 1 to 5 . A score of 1 indicates no or bad practices pertaining to the factor, and a score of 5 indicates best practices. The scoring guidelines are summarised in Tables 1 to 3 . The authors conducted the scoring initially; the scores were then verified with an environmental management practitioner in the OEM. An overall environmental performance rating for each company was calculated as follows:

$$
\mathrm{R}_{\mathrm{EP}}=\mathrm{S}_{\text {water }} \times \mathrm{S}_{\text {energy }} \times \mathrm{S}_{\text {waste }}
$$

A multiplicative model was used instead of an additive model to highlight small discrepancies between companies; the overall results would not be affected by the choice of either model. The environmental performance rating value $\left(R_{E P}\right)$ can therefore range from 1 , with no measurement or monitoring system and/or no 
compliance or evidence of compliance for any of the CP factors, to 125, with worldclass management practices for all the CP factors.

\section{Score Company practices for the cleaner production factor}

1 No measurement / monitoring system AND/OR No compliance / evidence of compliance.

2 No reduction of water usage programmes. No effluent reduction programme (if applicable).

3 Fair water management practices. Water usage monitored and some reduction programmes considered. Effluent monitoring and treatment/minimisation programmes considered.

$4 \quad$ Sound water management practices. Internal water usages measured and monitored per process/equipment. Some water usage reduction programs in place. If applicable, effluent measured and monitored per process/equipment. Some treatment/minimisation programmes in place.

5 Excellent world-class water management practices. Internal water usage monitored and reduction programmes implemented. Internal effluents monitored and treatment/minimisation programmes implemented.

Table 1: Score scale for the water usage and effluent release process parameters and management practices

\begin{tabular}{|c|l|} 
Score & \multicolumn{1}{c}{ Company practices for the cleaner production factor } \\
\hline 1 & No measurement / monitoring system. \\
\hline 2 & No reduction of energy usage programmes. \\
\hline 3 & $\begin{array}{l}\text { Fair energy management practices. Energy usage monitored and some } \\
\text { reduction programmes considered. }\end{array}$ \\
\hline 4 & $\begin{array}{l}\text { Sound energy management practices. Internal energy usages measured and } \\
\text { monitored per process/equipment. Some reduction programmes in place. }\end{array}$ \\
\hline 5 & $\begin{array}{l}\text { Excellent world-class energy management practices. Internal energy usage } \\
\text { monitored and reduction programmes implemented. }\end{array}$ \\
\hline
\end{tabular}

Table 2: Score scale for the energy usage process parameters and management practices 


\section{Score Company practices for the cleaner production factor}

\begin{tabular}{|c|l|}
\hline 1 & $\begin{array}{l}\text { No measurement / monitoring system AND/OR No compliance / evidence } \\
\text { of compliance. }\end{array}$ \\
\hline 2 & No waste reduction systems / policies / poor practices. \\
\hline 3 & $\begin{array}{l}\text { Fair waste management practices. Waste streams identified but not all } \\
\text { measured / quantified. }\end{array}$ \\
\hline 4 & $\begin{array}{l}\text { Sound waste management practices. Waste streams measured with some } \\
\text { recycling / external collaboration programmes where possible. }\end{array}$ \\
\hline 5 & $\begin{array}{l}\text { Excellent world-class waste management systems with total recycling / } \\
\text { external collaboration programmes implement. Fully compliant in terms of } \\
\text { international legislation. }\end{array}$ \\
\hline
\end{tabular}

Table 3: Score scale for the waste generation process parameters and management practices

The overall rating was then used to analyse and compare the environmental performances with:

- $\quad$ Company sizes;

- $\quad$ Financial dependencies on the specific OEM; and

- $\quad$ The status of formal EMS implementation, i.e. ISO 14000.

The OEM was selected as it is highly proactive on environmental issues, like other OEMs in South Africa. Twenty of the first-tier suppliers participated in the survey, representing over $40 \%$ of the total South African based suppliers of the OEM, and about $10 \%$ of the total registered automotive supplying companies in South Africa [18]. The majority of these (80\%) also supply other OEMs in the country and/or export. The twenty participating companies may represent the typical first-tier automotive supplying companies of South Africa (see Table 4).

\begin{tabular}{|l|c|c|c|}
\hline Company size & Number & Percentage of total & $\begin{array}{c}\text { Percentage with ISO } \\
\mathbf{1 4 0 0 0}\end{array}$ \\
\hline Large & 25 & 13 & 52 \\
\hline Medium & 131 & 66 & 33 \\
\hline Small & 42 & 21 & 10 \\
\hline
\end{tabular}

Table 4: Summary of the company profiles in the South African automotive component supply chain [18] 


\section{RESULTS}

The company profiles, with the scores for the Cleaner Production factors, and the calculated rating values, are summarised in Table 5. No company had an environmental performance rating value $\left(R_{E P}\right)$ of more than 48 (of the possible 125). This highlights that much needs to be done in the South African automotive supply sector in terms of Cleaner Production, which is also reflected in the poor accreditation of the companies in terms of formal EMSs (see Table 4). With respect to the company sizes:

- $\quad 3$ were large in size, with more than 500 employees;

- 14 were medium in size, with between 50 and 500 employees; and

- $\quad 3$ were small in size, with fewer than 50 employees.

Therefore, about two-thirds represent medium-sized companies, which corresponds to the profile of the 218 South African registered automotive supplying companies (see Table 4) [18]. The financial dependencies of the companies on the OEM were as follows:

- $\quad 3$ had little dependency, with $10 \%$ or less of the production associated with the OEM; all are medium in size;

- $\quad 9$ had a medium dependency, with between $10 \%$ and $50 \%$ of the production associated with the OEM; of these, 1 is large, 7 are medium, and 1 is small in size; and

- $\quad 8$ had a high dependency, with $50 \%$ or more of the production associated with the OEM; of these, 2 are large, 4 are medium, and 2 are small in size.

All of the companies had certified quality management systems (ISO 9000), while only the two medium-sized glass manufacturing companies had certified safety management systems (OSHAS 18001 or NOSA). Three-quarters of the companies had accredited EMSs (ISO 14000), of which 12 were medium in size and 3 were the large-sized companies. All of the large-sized companies were foreign-owned, whilst the medium-sized companies were a mixture of foreign- and locally-owned. None of the small-sized companies, all locally owned, had EMSs, which was also true of the locally-owned medium fuel tank and interior trim plastics parts manufacturers.

\section{DISCUSSION}

Figure 3 illustrates the relationship between the calculated $\mathrm{R}_{\mathrm{EP}}$ values of the suppliers (y-axis), the size of the companies (x-axis), and the status of implemented formal EMSs (data markers). Although an effective EMS can improve the environmental performance of a company, it is by no means a guarantee. Considering the mediumsized companies only, those with no formal EMS did, on average, have a good environmental performance compared with those with implemented formal EMSs. Rather, from the average $\mathrm{R}_{\mathrm{EP}}$ value line in Figure 3, it appears that company size is more important for overall environmental performance and compliance. 


\begin{tabular}{|c|c|c|c|c|c|c|c|c|c|c|}
\hline \multirow[t]{2}{*}{ No. } & \multirow{2}{*}{$\begin{array}{c}\text { Component/s } \\
\text { supplied }\end{array}$} & \multirow{2}{*}{$\begin{array}{l}\text { Company } \\
\text { size }^{\mathrm{a}}\end{array}$} & \multirow{2}{*}{$\begin{array}{c}\% \text { of } \\
\text { production }^{\mathrm{b}}\end{array}$} & \multicolumn{3}{|c|}{ Accreditation $^{c}$} & \multicolumn{3}{|c|}{ CP factor } & \multirow[t]{2}{*}{$\mathrm{R}_{\mathrm{EP}}$} \\
\hline & & & & 衤 & $\bar{\pi}$ & $\dot{\vec{\Xi}}$ & काँّ & 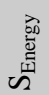 & $\omega^{\frac{\tilde{m}}{\pi}}$ & \\
\hline $\mathrm{S} 1$ & $\begin{array}{l}\text { Hand brake } \\
\text { assembly }\end{array}$ & Medium & 5 & $\mathrm{Y}$ & $\mathrm{N}$ & $\mathrm{Y}$ & 4 & 3 & 4 & 48 \\
\hline S2 & Fuel tank & Medium & 40 & $\mathrm{~N}$ & $\mathrm{~N}$ & $\mathrm{Y}$ & 3 & 3 & 3 & 27 \\
\hline S3 & $\begin{array}{l}\text { Air conditioner } \\
\text { hoses }\end{array}$ & Medium & 70 & $\mathrm{Y}$ & $\mathrm{N}$ & $\mathrm{Y}$ & 3 & 2 & 2 & 12 \\
\hline S4 & Paint & Medium & 20 & Y & $\mathrm{N}$ & $\mathrm{Y}$ & 2 & 1 & 4 & 8 \\
\hline S5 & Interior trim parts & Medium & 100 & $\mathrm{~N}$ & $\mathrm{~N}$ & $\mathrm{Y}$ & 3 & 2 & 4 & 24 \\
\hline S6 & Pressed metal parts & Large & 50 & $\mathrm{Y}$ & $\mathrm{N}$ & $\mathrm{Y}$ & 2 & 3 & 4 & 24 \\
\hline S7 & $\begin{array}{l}\text { Seatbelts bowden } \\
\text { cable }\end{array}$ & Small & 90 & $\mathrm{~N}$ & $\mathrm{~N}$ & $\mathrm{Y}$ & 2 & 1 & 2 & 4 \\
\hline S8 & Sunroofs & Small & 90 & $\mathrm{~N}$ & $\mathrm{~N}$ & $\mathrm{Y}$ & 2 & 2 & 4 & 16 \\
\hline S9 & Wiring Harnesses & Large & 100 & $\mathrm{Y}$ & $\mathrm{N}$ & $\mathrm{Y}$ & 3 & 3 & 4 & 36 \\
\hline S10 & Axle assembly & Medium & 100 & $\mathrm{Y}$ & $\mathrm{N}$ & $\mathrm{Y}$ & 3 & 2 & 3 & 18 \\
\hline S11 & $\begin{array}{c}\text { Assorted } \\
\text { components } \\
\text { (wiper, alternator, } \\
\text { etc.) }\end{array}$ & Large & 20 & $\mathrm{Y}$ & $\mathrm{N}$ & $\mathrm{Y}$ & 5 & 3 & 3 & 45 \\
\hline S12 & Rear-view mirrors & Medium & 40 & $\mathrm{Y}$ & $\mathrm{N}$ & Y & 2 & 2 & 4 & 16 \\
\hline S13 & Glass & Medium & 5 & $\mathrm{Y}$ & $\mathrm{Y}$ & $\mathrm{Y}$ & 2 & 2 & 4 & 16 \\
\hline S14 & electronic modules & Medium & 40 & $\mathrm{Y}$ & $\mathrm{N}$ & $\mathrm{Y}$ & 3 & 3 & 3 & 27 \\
\hline S15 & Stickers & Small & 20 & $\mathrm{~N}$ & $\mathrm{~N}$ & $\mathrm{Y}$ & 2 & 2 & 2 & 8 \\
\hline S16 & Window winders & Medium & 90 & $\mathrm{Y}$ & $\mathrm{N}$ & Y & 2 & 2 & 2 & 8 \\
\hline S17 & Air con unit / (h/e) & Medium & 10 & $\mathrm{Y}$ & $\mathrm{N}$ & $\mathrm{Y}$ & 3 & 4 & 4 & 48 \\
\hline S18 & Air con unit / (h/e) & Medium & 30 & $\mathrm{Y}$ & $\mathrm{N}$ & $\mathrm{Y}$ & 2 & 3 & 4 & 24 \\
\hline S19 & $\begin{array}{l}\text { Phosphating } \\
\text { chemicals / seals }\end{array}$ & Medium & 20 & $\mathrm{Y}$ & $\mathrm{N}$ & Y & 2 & 3 & 4 & 24 \\
\hline S20 & Glass & Medium & 20 & Y & $\mathrm{Y}$ & $\mathrm{Y}$ & 3 & 4 & 4 & 48 \\
\hline
\end{tabular}

a Large (more than 500 employees); Medium (between 50 and 500 employees); and Small (fewer than 50 employees).

b Percentage of production income that is attributable to the one OEM.

c Formal accreditation in terms of ISO 14000 (environmental), OSHAS 18001 or NOSA (safety), and ISO 9000 (quality).

Table 5: Summary of the company profiles, scores for the cleaner production factors, and calculated environmental performances ratings 


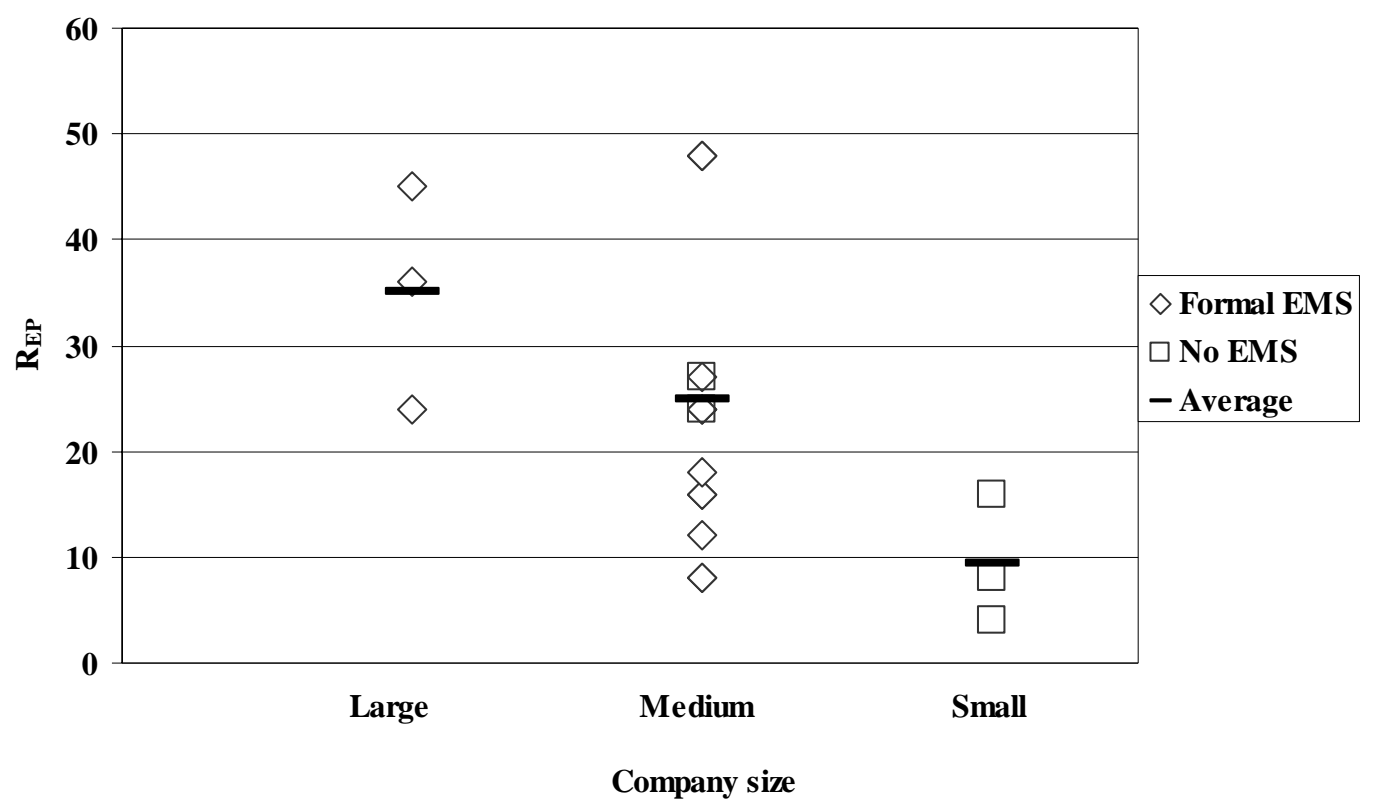

Figure 3: Environmental performance rating relating to implemented EMSs and company sizes

The abovementioned result is emphasised in Figure 4, which illustrates the relationship between the calculated $R_{E P}$ values of the suppliers (y-axis), the size of the companies (x-axis), and the financial dependency of the companies on the OEM (data markers). The dependency of the production output of a company on a single OEM customer does not imply good environmental performance. In fact, a higher dependency leans towards lower environmental performance. Again, company size determines the trends in environmental performances.

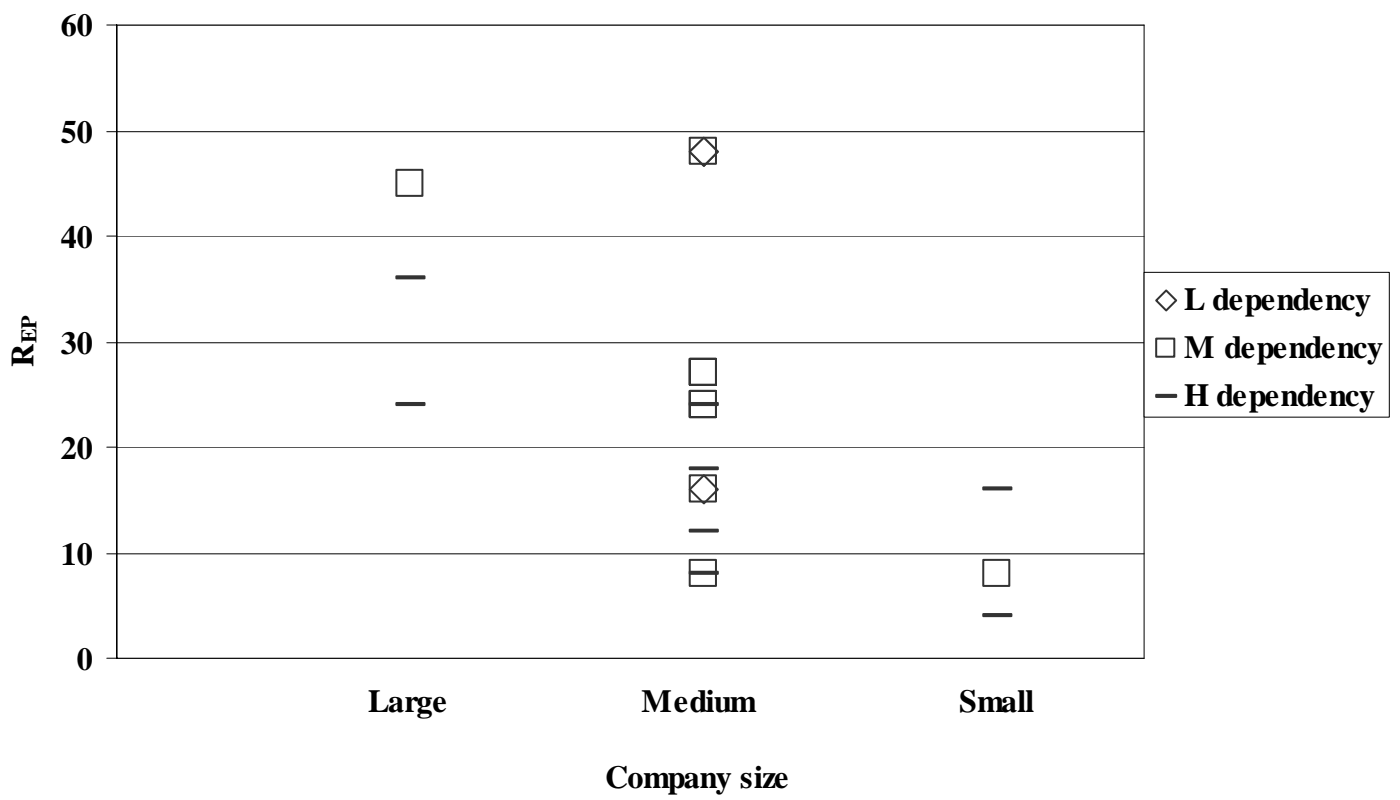

Figure 4: Environmental performance rating to financial dependency on one OEM and company sizes 


\section{CONCLUSIONS AND WAY FORWARD}

This paper has evaluated the implementation of Environmental Management Systems (EMSs) and the corresponding environmental performances of some first-tier companies in the current automotive supply chain of South Africa. This preliminary work focused on one OEM only, which makes the generalisation of the results problematic. For example, when compared with other countries, specific conditions pertaining to South Africa may or may not influence the outcomes observed.

From this pilot study, the most important factor that influences environmental performances appears to be the company size. The degree of financial dependency on an OEM is of lesser importance. Formal EMSs may lead to improved environmental performances if they are implemented effectively; what constitutes an effective implementation has yet to be resolved. Barriers to implementation have been documented in literature (see Section 1) [11]. To overcome these barriers it is subsequently proposed to modify the conventional EMS approach in the supply chain (see Figure 5). Rather than implementing separate EMSs, the concepts of existing supply chain models [14] are incorporated, whereby a more effective EMS can be developed for OEMs that integrates the external supply chain into the internal EMS (see Figure 6).

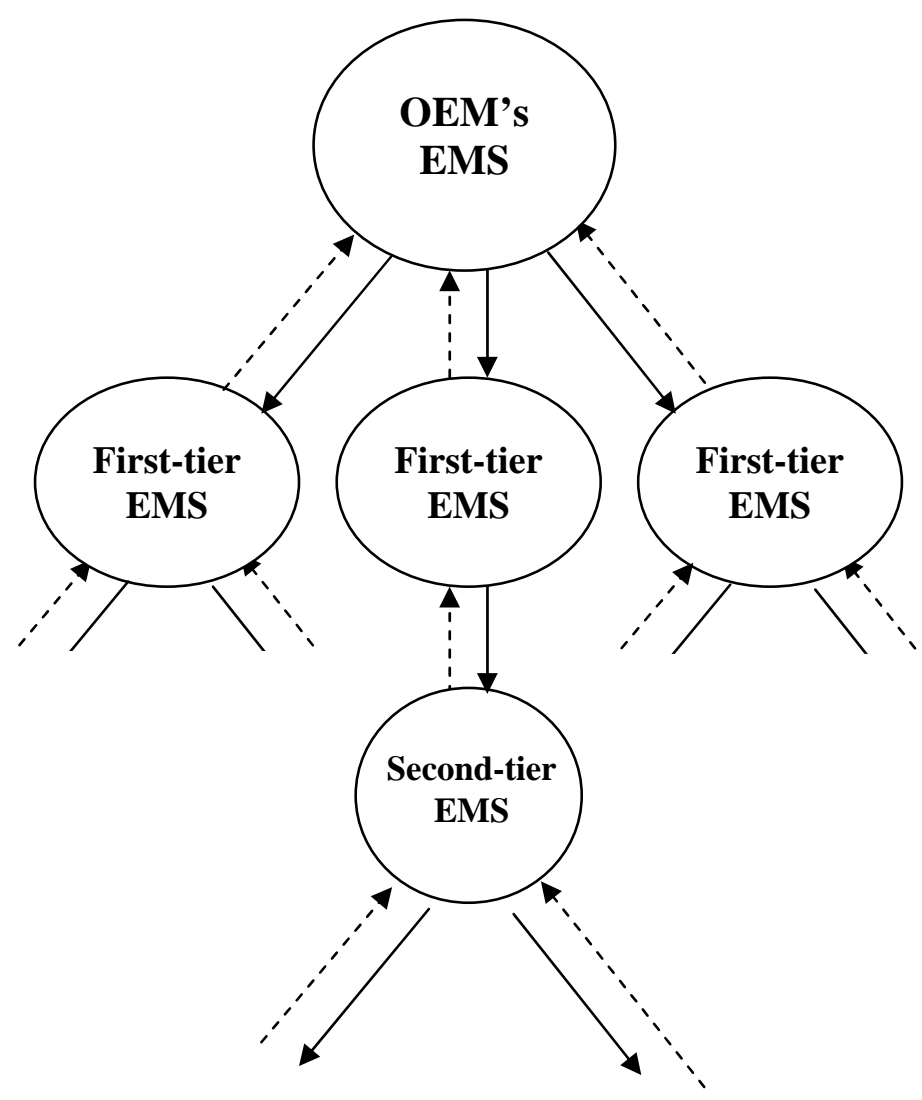

Solid lines depict the filtering of information down the supply chain between EMSs.

Dashed lines depict the limited feedback of information up the supply chain between EMSs.

Figure 5: Conventional EMS interaction in the supply chain 


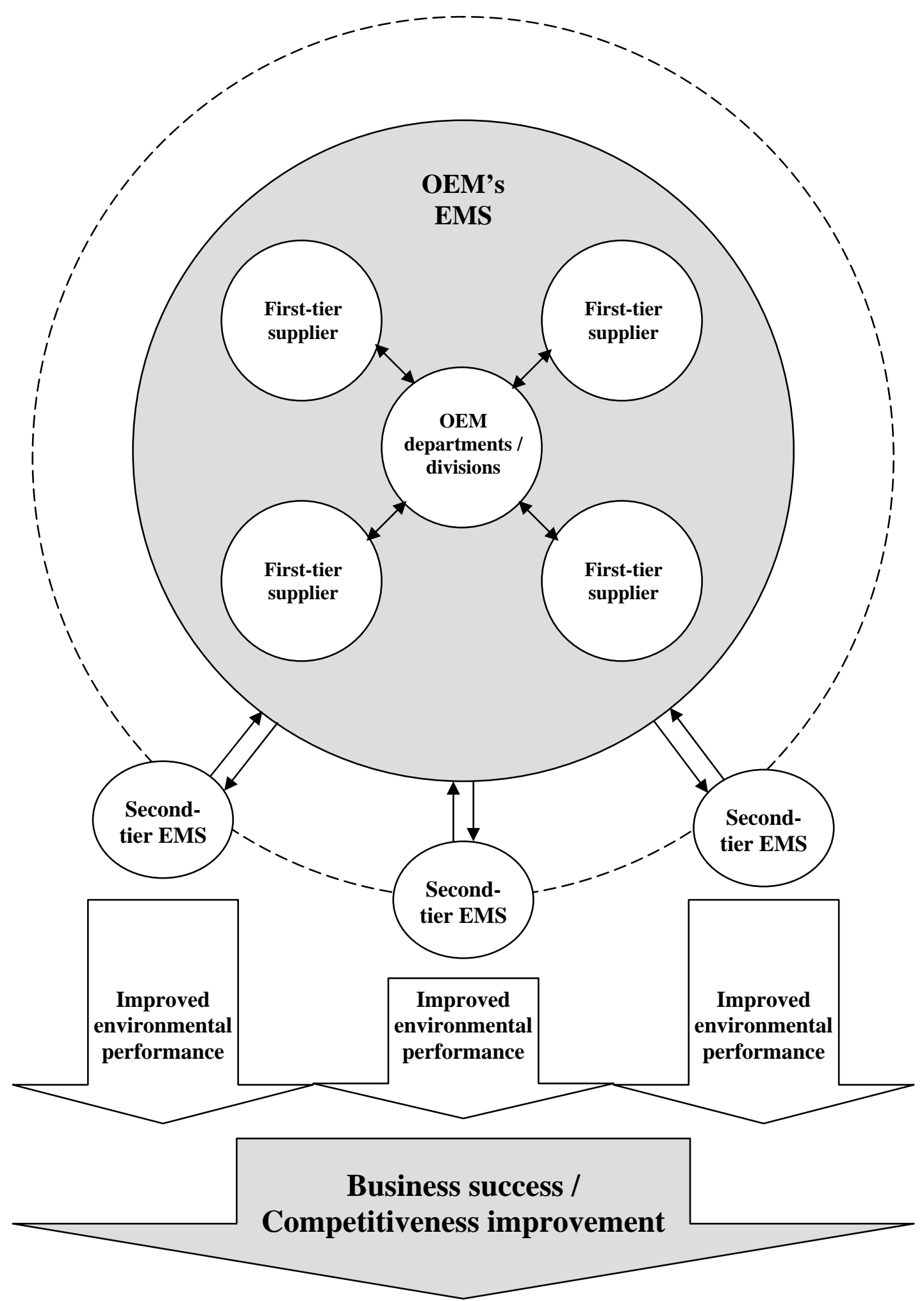

Figure 6: Proposed extension of OEM EMSs to include first-tier and subsequent suppliers 
The potential advantages of such a conceptual model are that:

- $\quad$ Communication between OEMs and the different parties in the supply chain is improved;

- $\quad$ Skills and knowledge from the OEMs to their supply chains are transferred, ensuring sound EMS compliance and cost effective systems;

- Partnering between OEMs and suppliers is closer, which results in the identification of additional opportunities, such as logistics and cost optimisation;

- An overall environmental performance improvement of the supply chain EMS can be achieved;

- $\quad$ Greener products at the end of the value chain can be delivered; and

- Investor confidence and company perception can subsequently be improved.

The disadvantage of such an EMS model is that suppliers may refuse to participate if, initially, there appear to be benefits, but the arrangement is later perceived to be a control mechanism of OEMs over suppliers. Similar cause-and-effects have been observed with previous supply chain models, and the concept therefore needs much analysis from more than a technical perspective, especially where first-tiers have lesser financial dependencies on single OEMs. The advantages and disadvantages of such a model are currently being investigated in the South African industry to develop a model that can be generalised outside the automotive sector.

\section{ACKNOWLEDGEMENTS}

The authors would like to thank the OEM and its participating first-tier suppliers for making the case study possible. Specifically, Dalene Viljoen, the Manager of Production Environmental Excellence of the OEM, is acknowledged for her insights and contributions, which initiated this research project.

\section{REFERENCES}

[1] Keeble, J.J., Topiol, S. and Berkeley, S. 2003. Using indicators to measure sustainability performance at a corporate and project level. Journal of Business Ethics, 44, pp 149-158.

[2] Goede, F. 2003. The future of SH\&E in the process industry with the focus on products. In: Labuschagne, C. and Brent, A.C. 2005. Sustainable Project Life Cycle Management: The need to integrate life cycles in the manufacturing sector. International Journal of Project Management, 23(2), pp 159-168.

[3] Global Environmental Management Initiative (GEMI). Website: http://www.gemi.org/index.htm, accessed on 14 June 2006.

[4] Beamon M.B. 1999. Designing the green supply chain. Logistics Information Management, 12(4), pp 332-342.

[5] Hussey D.M., Eagan P.D. and Pojasek R.B. 2002. A performance model for driving environmental improvement down the supply chain. In Proceedings, IEEE International Symposium on Electronics and the Environment, pp 107112. 
[6] Global Environmental Management Initiative (GEMI). Forging new links: Enhancing supply chain management through environmental excellence. Website: http://www.gemi.org/supplychain/, accessed on 14 June 2006.

[7] Pacific Northwest Pollution Prevention Resource Center (PPRC). Supply chain management for environmental improvement. Website:

http://www.pprc.org/pubs/grnchain/more.cfm, accessed on 14 June 2006.

[8] Fiksel, J. 1996. Design for environment: Creating eco-efficient products and processes. McGraw-Hill, New York.

[9] Winter, G. 1989. Business and the environment: A handbook of industrial ecology. McGraw-Hill, New York.

[10] Pimenova, P. and van der Vorst, R. 2004. The role of support programmes and policies in improving SMEs' environmental performance in developed and transition economies. Journal of Cleaner Production, 12(6), pp 549-559.

[11] Hillary, R. 2004. Environmental management systems and the smaller enterprise. Journal of Cleaner Production, 12(6), pp 561-569.

[12] Montabon, F., Melnyk, S.A., Sroufe, R. and Calantone, R.J. 2000. ISO 14000: Assessing its perceived impact on corporate performance. Journal of Supply Chain Management, 36(2), pp 4-16.

[13] Schylander, E. 2004. Environmental effects and organizational experiences of Environmental Management Systems. Licentiate thesis no. 25, Division of Quality and Environmental Management, Department of Business Administration and Social Sciences, Luleå University of Technology, Sweden.

[14] Supply Chain Council. SCOR tools and resources. Website: http://www.supply-chain.org, accessed on 14 June 2006.

[15] Supply Chain Council. SCOR case studies. Website: http://www.supplychain.org, accessed on 14 June 2006.

[16] National Cleaner Production Strategy

[17] South African Government. 1996. National Small Business Act. Act 102 of 1996, Website: http://www.acts.co.za/ntl_small_bus/index.htm, accessed on 14 June 2006.

[18] National Association of Automotive Component and Allied Manufacturers. NAACAM 2005 directory. Website: http://www.naacam.co.za, accessed on 14 June 2006. 